\title{
Individual Characteristics, Administration Preferences and Corruption: Evidence from Chinese Local Government Officials' Work Experience
}

\author{
Yexiao Luo, Longlong Duan \\ School of Economics and Management, Southwest Jiaotong University, Chengdu, China \\ Email: duanlonglong2006@126.com
}

Received 19 February 2016; accepted 19 April 2016; published 22 April 2016

Copyright (C) 2016 by authors and Scientific Research Publishing Inc.

This work is licensed under the Creative Commons Attribution International License (CC BY). http://creativecommons.org/licenses/by/4.0/

(c) (i) Open Access

\section{Abstract}

The Chinese corruption beyond the pressure-style fiscal decentralization system is largely dominated by the preferred duty performances decided by local political authorities. By designing a natural experiment about whether the officials leave their positions or not, the research combines the methods as difference-in-difference model and system generalized method of moments to explore the inter-correlation of the provincial party committee secretary's individual character, administration preferences and local corruption level in 30 provinces from 2000-2013 in China. The results show us that the exchange in different places and cross appointment for provincial party committee secretaries will be able to strength the anti-corruption mechanism; meanwhile, the intellectual officers and young and middle-aged chief leaders are more likely to carry on the shortterm encouraging policy. They are good at using their own employee experiences to encourage the officers from each level to form an "increasing-style promoting competition" order. The current Chinese anti-corruption strategy has obvious space-club effect and path dependence effect. In addition, the corruption attached to regional-scale can be gradually eliminated through the transfer of consumptive governmental expenses, fiscal decentralization reform, and continuous urbanization, enlarging the open areas. However, the lower corruption degree areas as west and middle areas may be trapped into another round of corruption as a result of the environment-sacrifice investment policies, which are caused by the employment expansion plan led by local leaders.

\section{Keywords}

Local Bureaucracy, Corruption, Individual Characteristics, Administration Preferences, Fiscal Decentralization 


\section{Introduction}

Today China's local economy is controlled by its top leaders and Chinese fiscal decentralization that combines vertical administrative subcontract and prefecture administration forms its system basis. The direction of local economic transition is decided by strategic orientation made by central government and individual administration preference of local government officials (Wang \& Xu, 2008). Bureaucratic tournament system that uses political promotion as incentives plays an assignable role in central government's control on the administration of local officials (Zhou, 2007). Although the tournament system that treats regional growth performance as key appraisal objectives can largely correct local officials' tendency of moral hazard, the spatial response of the system still needs to be enlarged for the existence of individual heterogeneity, such as age, and administration aspiration. Theoretically, serious economy rent-seeking and regional corruption will take place when individual rationality of local bureaucrats breaks the limit of political incentives.

Whether in western developed countries or in developing countries, corruption is a difficult problem in development which local governments at all levels have to face. The academic community considers that corruption caused by abusing public power for private benefits has different effects on regional economic growth in times of different economic stages ( $\mathrm{Li}, 2010)$. This shows that there is a significant nonlinear relation between corruption and economic growth. There are many factors which can cause corruption, but the most direct factors are local officials' private abusing of state power and personal behaviors centered on the swap of benefits. Recent years, with the constant improvement of our socialist market economy system and the beginning of a new round of fiscal decentralization reform targeted at enhancing local economic, a new round of competitions in fiscal expenditure among regions is aroused. While local governments enhance their capacity to derive fiscal resource, corruption frequently occurs in infrastructure investment, public service supply and investment attraction. Statistics show that since the beginning of this new century, the overall incidence of corruption in China dropped by about 30\% than 1990s, but the number of group corruption led by officials of department or bureau level even provincial and ministerial level has increased; especially after the Eighteenth National Congress of the CPC, decision-makers' high-pressure anti-corruption determination makes a large number of corrupt officials no place to hide ${ }^{1}$. However, this post-supervision system characterized by end-of-pipe control is not effective to keep group corruption and corruption involved exchange of power and interests within limits. The hot spot which concerns current domestic anti-corruption is what's the role of secretary of provincial party committee, the top leader who controls resources of local party and government and formation of bureaucracy, in local anti-corruption? Could the individual characteristics and administration preference of the secretary have significant impacts on local anti-corruption? Could a provincial secretary with multiple working experience, individual leadership authority and determination to develop local economy curb corruption incidence effectively? Studies have shown that most regional corruption directly related to political link of power and swap of power and money, while the carrier of benefits transmission undoubtedly lies in the administrative examination and approval authority of local bureaucratic system's inside. Therefore, to prevent formation of gradually solidified interest groups of powerful officials, long-term appointment of an official in one place should be avoided when developing anti-corruption system.

Right in the above background, the system of cadres exchange, cross appointment and off-post auditing comes into being in China. Throughout the existed researches, study on regional corruption from the perspective of local party and government top leaders' administration preference and individual authority characteristics has not yet appeared. The theoretical significance of this paper is filling the blank of anti-corruption research from the perspective of regional administration. And it helps to restrain local officials' short-term profit seeking behaviors from economic growth and internal governance through reshaping local bureaucracy by resetting the incentive structure for local top leaders.

\section{Literature Review}

Currently, studies about anti-corruption mainly involves following three areas:

The first is discussing basic connotation and category of corruption, clarifying specific definition of corruption and expansion boundary of corruption extension in different countries, economic system and historical background. For instance, some scholars believe that corruption in a broad sense means abuse of public role,

${ }^{1}$ By the end of January 2015, statistics of Central Commission for Discipline Inspection show that 76 officials in provincial and ministerial level (military officers included) fall down after the $18^{\text {th }}$ National Congress of the CPC, only eight provinces, Beijing, Shanghai, Jilin, Zhejiang, Fujian, Tibet, Ningxia, Xinjiang, have no officials in provincial and ministerial level been investigated and punished. 
resources, and public and private sectors' attempt to affect politic by illegal power (Hu, 2001), but this definition of corruption in fact admits the universality existence of corruption in national politics. In fact, the category of corruption is far more than that. The formation characteristics of corruption can be described more vividly from the perspective of the exercise of power. Once deviated from normative obligation and act of public role for benefits of money or position and abused power for personal gains, whether bribery, nepotism or improper possession all belong to corruption (Zhang, 2014). Therefore, power corruption becomes the most important form of corruption in developing countries. In addition, financial corruption is a high-risk area that needs special precautions in developing international anti-corruption strategies. In general, the definition summarized more comprehensively about the connotation of corruption emphasizes the process and behavior conducted by agents of public power to seek personal gains by power (Ren, 2009). The second is measurement of influence and social cost of corruption on economic growth in a country or a region. The principal point lies in the dispute that corruption is lubricant or a stumbling block in economic growth. The scholars who back the theory that corruption boosts economic growth believe that: as a way of resource allocation which replaces market competition, corruption can avoid bargaining mechanisms in liberal economy to save a lot of transaction costs. Moreover, as a way of forming alignment of interests, it is frequently used between the private and public sectors in developing countries with immature market economy for lower running costs of institutions. However, the scholars who support the theory that corruption constrains economic development emphasize corruption's distortion on resource allocation efficiency and damage on equilibrium condition maximized social welfare, what's more, the long-term negative effects brought by the absence of government administration and the lack of public service providing capability caused by serious corruption (Wei, 2001). Currently, majority of international empirical studies show that corruption in developed country shows negative correlations with economic growth (Mo, 2001; Hakeem, 2009), but in developing countries, it shows the feature of a inverted "U" (Shan, 2010). The third is systematical discussion on top-level design of anti-corruption system and bureaucratic incentive mechanism based on macro system design and state governance. A large number of research results in the field emerged after the $18^{\text {th }}$ National Congress of the CPC. But in all the prior studies involving corruption issues, literature focuses on the influence of local officials' individual behavior characteristics under local administration on regional corruption is rare. Recently, some literature start to pay attention to the impact of local officials' administration aspiration, political cycle, and cadres exchange on regional economic growth model and industrial transformation, which provides references to our further research. Xu et al. (2007) and Zhang (2007) creatively studied the relation between position redeployment of top leaders and local officials with control of economic management discretion and regional development. They discovered that a governor's or secretary of provincial Party committee's tenure in a prefecture and exchange in different prefectures have obvious positive effects on regional economic growth, and the achievement of this effect depends on industry development strategies and transformation orientation conformed to individual administration aspiration (Zhang, 2013). Similarly, political cycle and regional regime change will cause significant fluctuations on regional economy (Chen, 2010), and top leaders' working experience in different places and personal administration capacity will show more striking individual impacts in anti-corruption (Wei \& Wang, 2014). While the end elimination officials political incentives is the system accelerator that spurs performance competitions between secretaries of provincial Party committee and governors or their choice of corruption when they are going to leave the office (Chen, 2012).

To conclude, researches on the effect of the present cadre appointment system in China and administration preference on regional corruption have already begun but calls for further study. One of the difficulties in the study is to obtain comprehensive working information of provincial Party committee secretaries and governors of different provinces. Fortunately, previous studies provide much information for us. It's an innovation to take provincial Party committee secretaries' individual characteristics and administration preferences into anti-corruption researches. It contributes to understanding the implementation mechanisms of regional anti-corruption system affected by gradually expanding "feudal economy" and top leaders' autocracy under M type decentralization system of China, moreover, it provides new thoughts to central decision-makers and helps release more applicable anti-corruption policies.

The rest of the paper are as follows: the third part builds a research framework including provincial Party committee secretaries' individual heterogeneity, administration preference and regional corruption control, and defines and elaborates measuring methods of corresponding variables. The fourth part conducts an empirical study on provincial Party committee secretaries' individual heterogeneity, administration preference and region- 
al anti-corruption level by a Quasi-natural experiment and empirical research and draws corresponding conclusion. In the end of the paper is discussion and analysis of the conclusion.

\section{Research Design}

\subsection{Variables Design and Data Source}

\subsubsection{Individual Characteristics of Secretary of Provincial Party Committee}

In available literature, description about individual characteristics of local officials, especially about governor and secretary of provincial Party Committee, mostly remains on single index, generally used index includes age, sex, educational years, experience from enterprise and so on, and the age of secretary of provincial Party Committee is the often chosen proxy index in prior literature. Constrained by cadre's retirement age system in China, maximum administration age of secretary of provincial Party Committee is 65, which means that the secretary's age in the term can be a key factor that causes top leader's short-term behaviors before leaving the office (Zhou, 2007). While sex and experience from enterprise largely determine the secretary of provincial Party Committee's administration authority and differences in interpersonal strategies (Feng, 2013). In order to reflect secretary of provincial Party Committee's individual heterogeneity characteristics more comprehensively from multiple levels, the individual information of the secretary needs to be considered from various aspects. China's cadre selection system and public announcement system before appointment greatly reduce the difficulty of obtaining this information. Through searching resumes of the secretaries of provincial Party committee of different provinces in a certain period, variable set of the secretaries' individual characteristics is obtained, including the information about age, Party standing, outgoing or not, tenure, education level of different provinces. It should also be noted that, as rational individuals, corruption itself in the secretaries of provincial Party committee has big differences. The endogenous impacts of the secretaries' honest degree on regional corruption level must be taken into account, thus the influential factor that whether the secretary is corrupted or not needs to be evaluated when measuring the secretaries' individual characteristics ${ }^{2}$.

\subsubsection{Administration Preference of Secretary of Provincial Party Committee}

The change of secretary of provincial Party committee in China has obvious performance periodic characteristics (Li \& Zhang, 2014). As it’s known “a new broom sweeps clean”, newly appointed secretary of provincial Party committee has more motive to pursuit achievements than a secretary served years. Although, in academia, there is no clear definition standards on administration preference, traditionally, officials' administration preference still emphasize on officials' administrative actions in governance. Modern career prospect theory believes that in career planning, compared with professional managers' pursuit of equity incentive or material incentive, local officials within bureaucratic hierarchy pursue political promotion probability brought by administration performance. Therefore, under the constraint mechanism of Chinese bureaucratic tournament incentive promotion system, provincial party committee secretaries' administration preference we emphasized are characterized by coordination of personal administrative notions, central governance objectives and regional development demands. The secretaries combines administration preference of their own, rigid development obligation made by central government and regional people's livelihood standards improvement to make the index of administration preference that is the most suitable for career development, and these indexes happen to be reflected in the annual report of government of all provinces. It should be emphasized that though targeting at higher goals of regional economic growth and national economic development favors consistency incentive for officials to realize the anticipated growth targets, it also needs to consider the regional actual resource endowments and capacity of capital accumulation to avoid political dilemma caused by high aspirations with low abilities. To cater to the tournament incentive system used by central government to evaluate regional performance, the secretaries tend to make more robust and flexible ruling anticipated decisions so the obligatory evaluation targets and their own development index can realize at the same time.

Before the $17^{\text {th }}$ National Congress of the CPC, the indexes for performance appraisal for local officials set by the central government are restrained to the index of growth rate, income of residents and stability of national economy (inflation rate, unemployment rate), after 2008, the index of environmental protection and the index of

\footnotetext{
${ }^{2}$ From the situation of officials in provincial and ministerial level investigated and punished in 2000, corruption of the secretary of a provincial Party committee is rare, however, theoretically, the corruption preference of the secretary must be treated as a neutral variable, because participating in corruption is one of alternatives to realize political promotion.
} 
government debt ratio are adopted in the assessment system ${ }^{3}$. Considering the continuity of measurement on the secretaries' administration preference in their term of office and the intended development goals published in local government work reports, we use expected GDP growth rate, local fiscal revenue growth rate and the growth rate of per capita disposable income of urban and rural residents as alternative variables to the secretaries' administration preference. It should be noted, the author finds that there are significant differences in the three obligatory targets among provinces when collecting the annual government work reports from 2000 to 2012 in China. Some provinces, despite the announcement of next year's target of local GDP growth rate, but its volatility is very small, it seems to pay more attention to growth of local government's fiscal revenue and resident income, but some provinces (mainly the western regions) still stick to the theory of GDP growth, in addition, several other indexes have obvious heterogeneity. Therefore, in study, the three indexes need to be adjusted to weaken the weight differences in different indexes of provincial governments, geometric mean of different variables can solve this problem, thus it is wildly used when we measure the secretaries' administration preference to better reflect the real preference of administrators.

\subsubsection{Measurement of Local Corruption Level}

We argue that corruption is the process and behaviors that abuse public power for private gain under the entrust of public rights, so when measuring the level of corruption in a country or a region, most published literature use indexes, such as Corruption Perceptions Index (CPI) published by Transparency International and Corruption Control Index (CCI) published by the World Bank, but the corruption measurement index published by international institution mostly belongs to cross-country data and directly comes from their citizens' subjective impression on their officials, which has no help to the cross-province study of this paper. While objective corruption incidence built on published data of corruption investigation and punishment of a country is more help for this research (Wu \& Rui, 2010). Although some scholars believed that it is difficult to measure real index of corruption incidence, and it will underestimate the corruption level in China if only using the index of the number of registered corruption investigation and punishment cases and the index is affected by government's anti-corruption efforts, because policy will have a large disturbance effect on corruption cases (Zhu \& Gong, 2015). But in terms of the current research in academia, most scholars agree with using the objective corruption incidence as an evaluation index to measure the corruption in China (Zhao, 2015). Though after the $18^{\text {th }}$ National Congress of the CPC, the strengthened anti-corruption policy will have significant impact on registered corruption cases over a period, within the time of our study, anti-corruption policy has no major adjustment, thus the reliability of the corruption index is within acceptable limit ${ }^{4}$. Current corruption investigation and punishment data of China is mainly comprised by bribery, corruption, malpractice, and these data will be released to public by procuratorate authorities after annual census. Considering the different number of public officials caused by different population size of each region, effective evaluation index should be per capita corruption incidence when setting the index of regional corruption incidence. Thus we learn the research ideas from Zhou Li'an (2009), using registered corruption cases of public officers in per 10,000 persons of different provinces to conduct quantitative measurement on regional corruption level in China from 2000 to 2012.

\subsubsection{Other Control Variables}

In addition to the above factors, there are many other variables affect regional corruption level. The control variables we used here are consumption government expenditure proportion, degree of openness, urbanization rate, fiscal decentralization, registered urban unemployment rate, energy consumption per unit GDP index. These variables are chosen on two reasons. First, some or part of these control variables can reflect the dominant development index to evaluate the provincial party committee secretary's capability in some extent, so taking part or all of them into research can more clearly reflect what we are studying: the influence of the administration behaviors and administrative style of the secretary on regional corruption. Second, it has been proven that these control variables have significant statistical relevance to the incidence of local corruption, which is these factors that

\footnotetext{
${ }_{3}^{3}$ Bringing environment protection into local officials' performance appraisal is to restrain the industrial cluster of high pollution, high energy consumption and low efficiency industries which appeared under local government fiscal competition. And later carbon emission and air pollution control (PM 2.5) are also brought into assessment system. Bringing in local government debt is based on the rapid expansion of local government debt and the financial shortfall caused by fiscal deficit spending which will seriously affect local government's financial stability and local administration capacity.

${ }^{4}$ The $18^{\text {th }}$ National Congress of the CPC leads stronger action in anti-corruption. The fluctuation peak of the index of registered corruption cases appeared in 2013, for preciseness and feasibility of the study, the anti-corruption data we adopted is before the end of 2012.
} 
directly affect corruption incidence can have reverse change at the presence of individual differences and administration preference heterogeneity of provincial top leader. This change may benefits the policy change of decision-makers' evaluation and incentive system to local bureaucrats, thus it is a topic of great significance, and control variables can be obtained from Statistical Yearbook of China and Finance Yearbook of China.

\subsection{Research Idea and Model}

After giving the measurement of alternative variables respectively, we can use quantitative modeling method to make an empirical study on their causality. And there is another problem that needs to be noted. Whether the secretary of provincial Party committee left the office or not in individual characteristics mentioned above can not be directly used in regression model, because the time of top leadership transition in different provinces is very different, some provinces change their secretary of provincial Party committee several for several consecutive years. Therefore, it is necessary to specifically study the impact of regional leadership change on local corruption incidence. To testify the impact level of secretary of provincial Party committee's change on corruption incidence, we need to design a Quasi-natural experiment by using difference-in-differences (DID) proposed by Ashenfelter (1985).

Because we use panel data set, so a better sample model to design a Quasi-natural experiment is the panel data set of two periods' non observable data. In the whole sample data of 30 provinces and autonomous regions (excluding Tibet) in Chinese mainland from 2000 to 2013, the change of secretary of provincial Party committee is from 2 times to 5 times during 14 years. Because the situation that the Secretary has no change in the first year and all of them are changed in the second year does not exist, so we need to screen the provinces chosen as test samples. After careful screening, we chose 25 provinces and autonomous regions ${ }^{5}$ without change of provincial Party committee secretaries as control group and chose 25 provinces and autonomous regions with change of provincial Party committee secretaries as experimental group. We use Prog ${ }_{i t}$ to represent whether secretary of provincial Party committee is changed or not, so the first period is represented by $\operatorname{Prog}_{\mathrm{i} 1}=0$, the second period is $\operatorname{Prog}_{\mathrm{i} 2}=1$.

The panel model of non observable data is set as:

$$
Y_{i t}=\alpha_{0}+\delta_{0} \operatorname{Prog}_{i t}+Z_{i t} \beta+X_{i t} \gamma+c_{i}+u_{i t}
$$

in which, $Y_{i t}$ stands for dependent variable of province $i$ in period $t ; Z_{i t}$ for a group of observable control variables that change with time and affect $Y_{i t}$, it mainly includes five control variables: consumption fiscal expenditure proportion (CFD), openness (OP), urbanization rate (UR), fiscal decentralization (FD), energy consumption per unit GDP (CGDPE); $X_{i t}$ for a group of observable control variables that do not change with time and affects $Y_{i t}$, mainly including categorical variables (NCOR) like the provincial Party committee secretary's age (Old), term of office (Yea), education level and whether himself is corrupted or not. $c_{i}$ is non-observable effects, $u_{i t}$ is stochastic error, and $\alpha_{0}$ and $\delta_{0}$ are solve-for parameters. $\delta_{0}$ is the key parameter to be studied in this paper, because it shows the direct influence degree of changing the secretary of provincial Party committee on the dependent variables. Here we measure the dependent variables from two dimensions. One is studying other factors' influence, especially changing the secretary of provincial Party committee, on regional corruption; two is studying the influence of changing the secretary of provincial Party committee on the actual growth rate of the region.

The estimation in model (1), it can be realized by fixed effect of panel data, the parameter estimated by it is unbiased yet not robust. To improve the robustness of parameter estimation, here we also use difference-in-differences (DID) to conduct parameter estimation of the model. The realization of DID is by difference (1), and then the model changes into:

$$
Y_{i 2}-Y_{i 1}=\delta_{0} \operatorname{Prog}_{i 2}+\left(Z_{i 2}-Z_{i 1}\right) \beta+\left(u_{i 2}-u_{i 1}\right)
$$

In this model, constant term $\alpha_{0}$ in individual level, control variable set $X_{i t}$ that changes with time and non-observable effect $c_{i}$ are eliminated by difference, stochastic error $u_{i 2}-u_{i 1}$ is more close to the condition of independence variance. Thus solve-for parameter $\delta_{0}$ is more robust.

After solving the problem that whether the secretary of provincial Party committee is off post or not has im-

${ }^{5}$ The 25 provinces and autonomous regions are obtained from the whole sample of 30 provinces and autonomous regions excluding Liaoning Anhui, Fujian, Henan, and Chongqing. 
pact on corruption of the region, left key problem needs to be solved is to systematically measure the correlation degree of other variables involving the provincial Party Committee Secretary's individual characteristics and administration preference with regional corruption level. In this respect, system GMM estimation of dynamic panel data is right for the empirical demonstration of this paper. Relevant research shows that as a product of system and historical culture, Chinese corruption has obvious cross period and infection effects, this dependence cannot be eliminated by short-term economic or political system reform. Dynamic panel model is more precise for the practical requirements of econometric, because it considers term structure characteristics of economic variables. In order to fully reflect the correlation between different variables, we add the results of static estimation in empirical estimation to facilitate comparison. In static model, to adequately reflect regional differences, we built two virtual variables D1 and D2. If the province is in eastern region, then D1 $=1, \mathrm{D} 2=0$, and if the province is in the central and western regions, then $\mathrm{D} 1=0, \mathrm{D} 2=1$. In summary, econometric models required is:

$$
\operatorname{Cor}_{i t}=\alpha_{i}+\sum_{r=1}^{n} \beta_{r} \operatorname{Cori}_{t-r}+\sum_{\lambda=1}^{n} \phi_{\lambda} \operatorname{Ind}_{i t}+\eta_{0} \operatorname{Int}_{i t}+\sum_{\kappa=1}^{n} \tau_{k} \operatorname{Control}_{i t}+\mu_{i t}
$$

in which $i$ stands for province, $t$ for year, Cor for the incidents of corruption, Ind for the variable set of the local Party committee secretary's individual characteristics, Int for administration preference, Control for other control variables that affect corruption level, $\mu_{\mathrm{it}}$ for stochastic error. The descriptive statistics of all the variables used in model (3) are as follows (Table 1).

\section{Empirical Results and Analysis}

First of all, it reports the influence of changing secretary of provincial Party committee on corruption incidence and actual growth rate in a region. Table 2 shows the parametric estimation results of generalized least squares estimation method in two period panel data fixed effects model (model 1, model 2) and Robust estimation method in difference-in-difference model (DID) (model 3 and model 4). According to the report, we can easily find following rules: when dependent variable is corruption incidence of a region, electing new secretary of local provincial Party committee and change of power can curb further accumulation of corruption in a region, which might be realized by damaging the networks of interests alliance in a region and by changing the sustainability of local bureaucrats' administration expectation. Under the endogenous impact of political cycle, control variables that affect corruption incidence, like government consumption expenditure proportion, regional openness level, urbanization rate, government expenditure proportion fiscal decentralization and energy consumption per unit GDP have significant statistic relation.

Considering from the direction of parameters, government consumption expenditure proportion, openness level, and energy consumption per unit GDP present a positive relation to regional corruption level in China, while urbanization rate and government expenditure fiscal decentralization present a negative relation to corruption incidence. Theoretically, it is generally accepted that the expansion of government consumption expenditure is to comply with the demand of government function transformation to develop people's livelihood finance and it is also a manifestation of Wagner's law. But the consumption public expenditure in China mostly concentrated on the supply of club products, such as science, education, culture and public health, social security and environment protection; moreover, earmarks accounts for a high appropriation. Thus local governments use the network

\begin{tabular}{|c|c|c|c|c|c|c|c|c|c|c|c|}
\hline Variables & COR & INT & OLD & YEA & EDU & CFD & $\mathrm{OP}$ & UR & UNE & FD & CGDPC \\
\hline Mean & 29.82 & 9.97 & 59.23 & 3.26 & 17.35 & 0.45 & 0.33 & 0.47 & 3.65 & 0.028 & 1.42 \\
\hline Median & 27.89 & 9.39 & 60.0 & 3.00 & 16.0 & 0.45 & 0.13 & 0.447 & 3.70 & 0.025 & 1.228 \\
\hline Standard deviation & 11.71 & 2.05 & 4.18 & 2.16 & 1.95 & 0.08 & 0.41 & 0.15 & 0.71 & 0.015 & 0.77 \\
\hline Skewness & 2.47 & 0.64 & -0.73 & 1.39 & 0.75 & -0.02 & 1.89 & 0.96 & -0.57 & 1.13 & 1.59 \\
\hline Kurtosis & 20.29 & 2.80 & 3.56 & 5.83 & 2.73 & 2.34 & 5.56 & 3.64 & 6.73 & 4.82 & 5.65 \\
\hline Sample size & 420 & 420 & 420 & 420 & 420 & 420 & 420 & 420 & 420 & 420 & 420 \\
\hline
\end{tabular}


Table 2. Parameter estimation on local officials change, corruption and economic growth.

\begin{tabular}{|c|c|c|c|c|}
\hline \multirow{2}{*}{$\begin{array}{l}\text { Independent } \\
\text { variables }\end{array}$} & Model1 & Model 2 & Model 3 & Model 4 \\
\hline & $\begin{array}{l}\text { Dependent variable: } \\
\text { corruption }\end{array}$ & $\begin{array}{l}\text { Dependent variable: } \\
\text { economic growth }\end{array}$ & $\begin{array}{l}\text { Dependent variable: } \\
\text { corruption }\end{array}$ & $\begin{array}{l}\text { Dependent variable: } \\
\text { economic growth }\end{array}$ \\
\hline $\mathrm{C}$ & $\begin{array}{l}49.51^{* * *} \\
(5.95)\end{array}$ & $\begin{array}{l}37.49^{* * *} \\
(9.56)\end{array}$ & & \\
\hline Pro & $\begin{array}{l}-1.30^{* *} \\
(-2.46)\end{array}$ & $\begin{array}{l}-0.70^{* *} \\
(-2.69)\end{array}$ & $\begin{array}{l}-1.65^{* * *} \\
(-24.27)\end{array}$ & $\begin{array}{l}-1.71^{* * *} \\
(-2696.7)\end{array}$ \\
\hline CFD & $\begin{array}{l}23.08^{* * *} \\
(6.70)\end{array}$ & $\begin{array}{l}19.29^{* * *} \\
(5.51)\end{array}$ & $\begin{array}{l}25.41^{* * *} \\
(41.49)\end{array}$ & $\begin{array}{l}22.34^{* * *} \\
(3918.1)\end{array}$ \\
\hline OP & $\begin{array}{l}9.33^{*} \\
(1.88)\end{array}$ & $\begin{array}{l}-1.01 \\
(-0.27)\end{array}$ & $\begin{array}{l}8.76^{* * *} \\
(29.81)\end{array}$ & $\begin{array}{l}-3.66^{* * *} \\
(-1337.2)\end{array}$ \\
\hline UR & $\begin{array}{l}-73.0^{* * *} \\
(-3.88)\end{array}$ & $\begin{array}{l}-61.18^{* * *} \\
(-5.52)\end{array}$ & $\begin{array}{l}-66.21^{* * *} \\
(-24.32)\end{array}$ & $\begin{array}{l}-51.2^{* * *} \\
(-2019.7)\end{array}$ \\
\hline FD & $\begin{array}{l}-175.3^{* * *} \\
(-2.88)\end{array}$ & $\begin{array}{l}373.9^{* * *} \\
(10.21)\end{array}$ & $\begin{array}{l}-152.2^{* * *} \\
(-16.73)\end{array}$ & $\begin{array}{l}411.5^{* * *} \\
(4858.7)\end{array}$ \\
\hline CGDPC & $\begin{array}{l}2.51^{* *} \\
(2.25)\end{array}$ & $\begin{array}{l}-6.72^{* * * *} \\
(-17.68)\end{array}$ & $\begin{array}{l}2.11^{* * *} \\
(21.44)\end{array}$ & $\begin{array}{l}-6.64^{* * * *} \\
(-7252.2)\end{array}$ \\
\hline R-square & 0.994 & 0.999 & 0.286 & 0.775 \\
\hline Model & $\mathrm{FE}$ & $\mathrm{FE}$ & DID & DID \\
\hline Method & GLS & GLS & Robust estimation & Robust estimation \\
\hline
\end{tabular}

of their Beijing offices to lobby in various ministerial departments for approval authority of special transfer payments is often happens, which will induced longitudinal corruption around interests transmission. The energy consumption per unit GDP present a positive relation to the regional corruption, which means that attracting business and investment as traditional ways of regional rapid capital accumulation still remains on introducing low-end, high-pollution and high-energy consuming industrial enterprises to realize economic growth. The industry introduction and preferential policies are directly decided by local officials. Thus if it is clear against national principles and policies, high-pollution enterprises can only get approval by corrupting local officials, and then the corruption caused by officials' collusion with merchants is unavoidable. Another point is the impact of openness on regional corruption. Most literature believes that openness helps curb officials' corruption, but estimation results in this paper is in the opposite. If the purpose of regional open is to introduce technology, to expand regional market size and to form a big regional markets of specialized division of labor, then opening is conducive to curb power corruption by improving the efficiency of resource allocation; but if the purpose of regional open is to attract investment and business and the projects attracted are high input, high consumption, high pollution and low efficiency industry and extensive industry, then the so-called open will become a system accelerator of regional corruption accumulation.

While what comforts us is that gradually expanding decentralization reform and urbanization strategy help reduce local corruption incidence and the change of top leader helps central government's fiscal decentralization incentives turn to economic development, which is more obvious when the dependent variable is regional economic growth. Although the handover between local secretary of the provincial Party Committee lower the local economic growth in a certain extent, but by strengthening the administration expectation of local bureaucracy and recognition to policy of central government, it can correct the officials' short-term irrational behaviors, which mainly shows in increasing consumption government expenditure and adjusting regional industrial structure. This change benefits from multiple institutional factors, such as the tenure limit of cadres, cadres exchange and young cadres construction released by central government.

Next, we will see how local provincial Party committee secretary's individual characteristic variables affect the incidence of corruption. In report 3, the results of corresponding parameters are fully displayed through system GMM method in dynamic panel data model and generalized least squares estimation of static panel data mode. In the process of dynamic panel estimation, to obtain the robust estimator of key estimation parameter, we need to fix the endogenous problems of variables. In estimation, the problems are solved by Sargan test 
through one by one test. And the Arellano-Bond test shows that dependent variable has first-order lag effect. Summed up, the estimation results by dynamic and static panel are as follows: first, Chinese corruption has significant cross period ratcheting effect, local corruption often directly related to long-term historical evolution and cultural embedding. Second, the administration preference, individual characteristics of secretary of provincial Party committee have apparent heterogeneity with local corruption level. Specifically, secretary of provincial Party committee with strong administration willingness and long political career is tough toward corruption; and for the top leader who is sensitive to performance evaluation, longer educational years make them more antipathy to corruption in individual emotion, and it will urge the secretary to carry out official administration of his prefecture in his tenure. However, if the secretary of provincial Party committee has weak administration willingness and is indifferent to the central government's tournament incentive mechanism, then the phenomenon that a secretary of provincial Party committee often corrupts in 64 years old will happen. This situation becomes more obvious when control variable is adopted. Now most provincial and ministerial cadres are investigated and punished just before their leaving the position, which reflect the seriousness of corruption before leaving the offices. Considering the honesty of the secretary of provincial Party committee himself, we find that corruption's individual heterogeneity inside the group of secretary will significantly affect the administration effectiveness of anti-corruption in its prefecture. The serious consequences of the secretary of provincial Party committee is directly involved in corruption will form vertical bureaucratic protection centered by interests. And by administrative intervention and judicial control, corruption level in his prefecture is underestimated. Third, the internal variables decided by secretary of provincial Party committee's individual characteristics show differences to regional corruption. Overall, the educational level of regional top leader is the greatest individual factor that impacts the incidence of local corruption, followed by secretary of provincial Party committee's age and tenure. Under comprehensive consideration of the secretary's administration willingness, his term in the office in a prefecture is no longer the key factor that impact regional corruption, on the contrary, focusing on the secretary's administration preference is the key to ease the accumulation of corruption. Fourth, in other control variables that affects regional corruption, if the secretary's administration will and individual characteristics are fully considered, then increasing government consumption expenditure, expanding open up, accelerating the construction of urbanization, and the decentralization reform that implements local financial autonomy can control Chinese corruption. However, if the secretary continuously pay attention to the improvement of unemployment and put it as a important obligatory target of administration in a long term, then sustainable energy-saving and emission-reduction will be difficult to achieve, especially in backward western region. If considering unemployment rate and energy consumption per unit GDP at the same time, local officials tend to make short-term decisions, that is, inducing in labor-intensive and high-pollution enterprises in exchange for employment, then regional corruption will increase (Table 3 ).

\section{Conclusion Remarks}

Discussion on the mechanism of regional corruption under unitary state and government-led economic growth pattern should fully consider the influence of individual characteristics and administration preferences of local leaders. It is an essential way to deeply understand the root of corruption from the political behavior and administration concept of the secretary of provincial party committee. Seeing from the spatial distribution of provincial corruption incidence in the $12^{\text {th }}$ Five-Year Plan period, the spatial layout of overall corruption is approximately accord with so-called "Hu conditions" ${ }^{3}$ in demography and we named it the new Aihui-Tengchong line of the corruption spatial distribution in China. And seeing from the evolution of spatial distribution of corruption in provinces in the past 10 years, China's regional corruption has an obvious characteristic of the space club; the phenomenon of spatial group corruption is arresting and local officials' corruption is beginning to be affected by spatial externality of bureaucratic corruption in neighboring provinces and form unified strategy interaction (Wang et al., 2013). Therefore, when the central government makes national anti-corruption strategy, it needs to combine the individual incentive mechanism and the exchange of cadres to form individual, prefecture, region three-level longitudinal joint defense system that covers an officials' whole political career.

\footnotetext{
${ }^{6}$ Traditional Hu line mainly emphasizes the relation between land resources distribution and population agglomeration, but in the research of this paper, it uses the number of registered cases of public officials corruption in per 10,000 persons as the index of corruption incidence. And this index is a homogeneous index that has eliminated the influence of provincial population scale, thus population scale has no error effect on corruption, but it still has spatial characteristics of Hu line, which again shows that Chinese corruption has deep historical and cultural incentives.
} 
Table 3. Parameter estimation about individual characteristics of party secretary, administration preference and corruption.

\begin{tabular}{|c|c|c|c|c|c|c|}
\hline Independent variables & $\begin{array}{l}\text { Model } 1 \\
\text { SYS-GMM }\end{array}$ & $\begin{array}{l}\text { Model } 2 \\
\text { SYS-GMM }\end{array}$ & Model 3 OLS & $\begin{array}{c}\text { Model } 4 \\
\text { OLS }\end{array}$ & $\begin{array}{l}\text { Model } 5 \\
\text { GLS }\end{array}$ & $\begin{array}{c}\text { Model } 6 \\
\text { GLS }\end{array}$ \\
\hline $\mathrm{C}$ & $\begin{array}{l}81.4^{* * *} \\
(4.48)\end{array}$ & $\begin{array}{l}33.62^{* * *} \\
(8.61)\end{array}$ & & & $\begin{array}{l}87.5^{* * *} \\
(13.4)\end{array}$ & $\begin{array}{l}43.5^{* * *} \\
(13.2)\end{array}$ \\
\hline L1.Cor & $\begin{array}{l}0.52^{* * *} \\
(6.06)\end{array}$ & $\begin{array}{l}0.74^{* * *} \\
(19.75)\end{array}$ & & & & \\
\hline GOA & $\begin{array}{l}-0.51^{* *} \\
(-2.6)\end{array}$ & & $\begin{array}{l}-1.43^{* * *} \\
(-4.79)\end{array}$ & $\begin{array}{l}4.15^{* * *} \\
(5.11)\end{array}$ & $\begin{array}{l}-0.12 \\
(-0.85)\end{array}$ & $\begin{array}{c}-1.11^{* * *} \\
(-8.9)\end{array}$ \\
\hline OLD & $\begin{array}{l}-0.37^{*} \\
(-1,96)\end{array}$ & & $\begin{array}{l}-0.29^{* *} \\
(-2.10)\end{array}$ & $\begin{array}{l}-1.42^{*} \\
(-1.88)\end{array}$ & $\begin{array}{l}-0.21^{* * *} \\
(-3.1)\end{array}$ & \\
\hline YEA & $\begin{array}{c}0.07 \\
(1.44)\end{array}$ & $\begin{array}{l}0.57^{* * *} \\
(3.76)\end{array}$ & $\begin{array}{l}-0.18 \\
(-0.73)\end{array}$ & $\begin{array}{l}-3.17^{* * *} \\
(-18.12)\end{array}$ & $\begin{array}{c}0.05 \\
(0.45)\end{array}$ & $\begin{array}{l}-0.14^{*} \\
(1.61)\end{array}$ \\
\hline EDU & $\begin{array}{l}-1.46^{* * *} \\
(-3.39)\end{array}$ & & $\begin{array}{l}-0.78^{* * *} \\
(-2.70)\end{array}$ & $\begin{array}{l}1.68^{* * *} \\
(11.03)\end{array}$ & $\begin{array}{l}-0.21 \\
(-1.38)\end{array}$ & $\begin{array}{l}-0.49^{* * *} \\
(-3.37)\end{array}$ \\
\hline NCOR & & $\begin{array}{l}-11.12^{* * *} \\
(-6.19)\end{array}$ & & $\begin{array}{l}15.1^{* * *} \\
(15.0)\end{array}$ & & \\
\hline CFD & $\begin{array}{c}1.30 \\
(0.21)\end{array}$ & $\begin{array}{l}-47.0^{* * * *} \\
(-8.19)\end{array}$ & $\begin{array}{l}-14.47^{* *} \\
(-1.97)\end{array}$ & $\begin{array}{l}46.2^{* * * *} \\
(22.1)\end{array}$ & $\begin{array}{l}5.59^{*} \\
(1.70)\end{array}$ & \\
\hline $\mathrm{OP}$ & $\begin{array}{c}4.24 \\
(1.32)\end{array}$ & $\begin{array}{l}-9.38^{* * *} \\
(-9.32)\end{array}$ & $\begin{array}{l}-7.6^{* * *} \\
(-1.86)\end{array}$ & $\begin{array}{l}-23.3^{* * *} \\
(-10.79)\end{array}$ & $\begin{array}{l}-1.16 \\
(-0.59)\end{array}$ & $\begin{array}{l}-7.15^{* * *} \\
(-3.95)\end{array}$ \\
\hline UR & $\begin{array}{l}-24.5^{* *} \\
(-2.13)\end{array}$ & & $\begin{array}{l}-7.11 \\
(-1.06)\end{array}$ & $\begin{array}{l}33.3^{*} \\
(1.82)\end{array}$ & $\begin{array}{l}-73.5^{* * *} \\
(-10.87)\end{array}$ & \\
\hline UNE & $\begin{array}{l}-0.18 \\
(-0.17)\end{array}$ & $\begin{array}{l}3.02^{* * *} \\
(3.96)\end{array}$ & $\begin{array}{l}3.06^{* * *} \\
(3.96)\end{array}$ & $\begin{array}{c}24.32^{* * *} \\
(21.81)\end{array}$ & $\begin{array}{l}-1.02^{*} \\
(-1.84)\end{array}$ & \\
\hline FD & $\begin{array}{l}-69.2^{*} \\
(-1.74)\end{array}$ & & $\begin{array}{c}-91.7^{* * *} \\
(-2.2)\end{array}$ & $\begin{array}{c}357.5^{* * *} \\
(6.87)\end{array}$ & $\begin{array}{c}-208.6^{* * *} \\
(-4.62)\end{array}$ & \\
\hline CGDPC & $\begin{array}{l}-2.50 \\
(-1.56)\end{array}$ & $\begin{array}{c}-10.46^{* * *} \\
(-544)\end{array}$ & $\begin{array}{l}-0.48 \\
(-0.58)\end{array}$ & $\begin{array}{l}21.48^{* * *} \\
(14.54)\end{array}$ & $\begin{array}{l}1.36^{* *} \\
(1.91)\end{array}$ & $\begin{array}{l}5.84^{* * *} \\
(10.13)\end{array}$ \\
\hline D1 & & & $84.26^{* * *}$ & & & \\
\hline $\mathrm{D} 2$ & & & $75.77^{* * *}$ & & & \\
\hline $\begin{array}{l}\text { Arellano-Bond test for } \\
\text { AR (1) }\end{array}$ & -1.15 & -1.16 & & & & \\
\hline $\begin{array}{l}\text { Arellano-Bond test for } \\
\text { AR (2) }\end{array}$ & 1 & 1.09 & & & & \\
\hline $\begin{array}{c}\text { Sargan test/Hausman } \\
\text { test }\end{array}$ & $127.81(1)$ & 7.59 (1) & & & $66.7^{* * *}$ & $16.93^{* * *}$ \\
\hline Method & Two-step & Two-step & OLS & OLS & $\mathrm{FE}$ & FE \\
\hline
\end{tabular}

Notes: ${ }^{*},{ }^{* *}$ and ${ }^{* * *}$ indicate the significant level at $10 \%, 5 \%$ and $1 \%$, respectively.

By using 170 provincial party committee sectaries' resumes and 420 annual government work reports of 30 provinces and autonomous regions in Mainland China, this paper systematically studies the influence of provincial party committee sectaries' individual heterogeneity and administration preferences on the incidence of corruption and draws an abundant research conclusion.

In the complex anti-corruption struggle in our country, these conclusions are of highly practical significance; therefore, it is necessary to sum up the final results of all empirical studies. It covers following aspects:

First, local power transfer system that adopts the exchange of cadres, cross appointment and normal power change is a "double-edged sword" that affects local development. Although it helps lower the speed of corruption by restricting local interest curing brought by long-term administration of the same bureaucracy, it can hinder the sustainability of local policies and development strategies and lower regional economic growth. The key to balance them lies in the different administration preference of secretary of provincial party committee.

Second, secretary of provincial party committee with more years of education and experience has lower tolerance to local corruption and stronger determination to anti-corruption. While the tenure of the secretary in a prefecture is not the key factor to affect local corruption. Compared with the provincial party committee secreta- 
ries' individual characteristics, having a performance incentive that responds to a performance promotion and a administration preference for regional economic growth is more important in weakening the level of local corruption. It can be achieved by improving a series of regional economic conditions, such as the structure of government consumption expenditure, the level of openness, urbanization rate, the level of fiscal decentralization and energy consumption per unit GDP. And surely, one of the preconditions to achieve these goals is the integrity of the provincial party committee secretary.

Third, what cannot be ignored is the path dependence formed by long-term corruption accumulation. It is the endogenous factor contained in Chinese bureaucratic system and historical and cultural inheritance. Therefore, source control and end-of-pipe control are equally important when it comes to anti-corruption. In the support and inspiration of above conclusions, the timing to adjust top leader, strategy replacement and bureaucratic assessment system can be optimized. Considering the factors that affect corruption, it is not enough to prevent corruption in the region by enhancing the frequency of exchange of cadres. When implementing the system of cross appointment and exchange of cadres, it also needs to increase the cross stage performance evaluation of officials in exchange and to promote local officials who are dedicated to developing regional economy in a long term and have strong administration preference. Besides, it is completely correct for the central government to implement the policy of reducing the average age of cadres and making cadres knowledge elite. However, cadres' tenure should be further shorted and their change should be more frequent. Especially under the new normal economic growth mode, the current economic growth is further slowed; thus further emancipating the mind, releasing the dividends of reform and promoting institutional innovation are needed. And it is time to appoint a group of young, promising, innovative top leaders with regional crisis awareness. Finally, it needs to be emphasized that the results of the study confirmed the involution of Chinese corruption; therefore, the authorities should be aware of the long-term and arduous nature of anti-corruption strategy. The eastern region has a higher corruption incidence than the western region; therefore, to lower "ratchet effect" of corruption, group replacement can be adopted in designing the system of cadre selection and cross appointment. Replacing all the top leaders in a region of high corruption incidence can prevent the locking phenomenon's self-replication and curing.

There still is something in our study that can be improved. There is a large room for expansion in quantitative indicators that measure local officials' individual characteristics and administrative preference. Particularly in the measurement of administrative preference, more scientific measurement indexes can be established by field interviews and scale development and officials tested can range from chief leaders in a province or a city to primary government officials; therefore, more accurate study conclusion can be obtained.

\section{References}

Chen, G. (2012). Exchanges of Officials, Tenure and Anti-Corruption. World Economy, 12, 120-141.

Chen, W. D. (2010). Change of Government, Economic Policy and Political Economic Cycle. Economic Survey, 4, 14-19.

Feng, Y. (2013). Economic Factors in the Promotion of Chinese Officials. Journal of Management Sciences in China, 11, 55-67.

Hakeem, I. M. (2009). Corruption and Economic Growth in Some Selected Transitional Economies. Social Responsibility Journal, 1, 70-82.

Hu, A. G. (2001). China: Challenging Corruption. Hangzhou: Zhejiang People Press.

Li, G. Z. (2010). Kuznets Curve Effects of Economic Growth in China and Corruption. Finance and Trade Research, 1, 6570.

Li, H. J., \& Zhang, Z. Y. (2014). Local Officials Tenure, Corruption and Firm R \& D Investment. Studies in Science of Science, No. 5, 744-756.

Mo, P. H. (2001). Corruption and Economic Growth. Journal of Comparative Economics, 29, 66-79. http://dx.doi.org/10.1006/jcec.2000.1703

Ren, J. M. (2009). Corruption and Anti-Corruption: Theory, Models and Method. Beijing: Tsinghua University Press.

Wang, W., Hu, J., Zong, Q. Q., \& Guo, F. (2013). Strategic Interaction between Officials of Corruption: Theory and Evidence. China Industrial Economics, No. 10, 31-42.

Wang, X. B., \& Xu, X. X. (2008). Local Officials Origin, Destination, Term of Office and Economic Growth. Management World, No. 3, 16-26.

Wei, J., \& Wang, A. (2014). Determine the Level of Anti-Corruption: Official Communication and Independence. Economic 
and Management Research, No. 11, 98-106.

Wei, S. J. (2001) Economical Bribery: Lubricant or Sand? Comparative Economic \& Social Systems, No. 1, 33-43.

Wu, Y. P., \& Rui, M. (2010) Region Corruption, Market and Economic Growth in China. Management World, No. 11, $10-17$.

Xu, X., Wang, X., \& Shu, Y. (2007). Local Officials and Economic Growth: Evidence from China Governor, Party Secretary of Communication. Economic Research Journal, No. 9, 18-31.

Zhang, E. S. (2013) Personal Characteristics and Regional Industrial Structure Optimization of Local Officials. China Soft Science, No. 6, 71-83.

Zhang, H. F. (2014) The Internal Mechanism of Official Corruption and Governance Network Construction. Journal of the Party School of the Central Committee of the C.P.C., No. 8, 42-46.

Zhang, J. (2007). Official Term, Remote Exchange and Economic Growth: Evidence from Provincial Experience. Economic Research Journal, No. 11, 91-102.

Zhu, L., \& Gong, F. J. (2015). The Difference between Objective and Subjective Measurements on Corruption. Comparative Economic \& Social Systems, No. 5, 66-79.

Zhou, L. A. (2007). Study on Chinese Local Officials Promoted Championship Mode. Economic Research Journal, No. 7 , 36-50.

Zhou, L. A. (2009). Transformation of Local Government: Officials Incentive and Governance. Beijing: Peking University Press.

Zhao, Y. (2015). Corruption and Firm Growth: Empirical Evidence from China. Economic Perspectives, No. 7, 35-49. 